\title{
BATHYMETRIC MAP OF NAVARIN BASIN PROVINCE, NORTHERN BERING SEA
}

by Jeffrey M. Fischer, Paul R. Carlson, and Herman A. Kar1

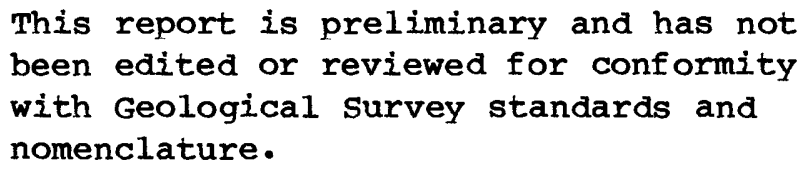

\section{INTRODUCTION}

This bathymetric map of the Navarin basin province is part of the ongoing research in preparation for OCS Lease sale 83 which is scheduled for the spring of 1984. The intended use of this map, in addition to showing the morphology of the Navarin continental margin, is for the plotting of geologic and geophysical data. It is not intended for use in navigation. Names used herein for seafloor features are from historical and general usage and have not been formally approved.

Navarin basin province includes an area of over $150,000 \mathrm{~km}^{2}$ and contains the large, deep, sediment-filled Navarin basin named by Marlow and others, (1976). The study area is located in the northern Bering sea (see index map) and extends to within $100 \mathrm{~km}$ of St. Matthew Island on the northeast and to within $100 \mathrm{~km}$ of St. Paul Island on the southeast. To the southwest, the boundary of the study area is the $3600 \mathrm{~m}$ isobath, and to the northwest, the U.S.-Russia Convention Line of 1867; however, the basin itself continues to within $150 \mathrm{~km}$ of the Siberian Coast (Marlow and others, 1981b). 
Previous studies of the Bering Sea have concentrated on the Siberian and Alaskan coasts, in addition to the Aleutian Arc and portions of the southeastern Bering continental margin. Within the Navarin basin province, few studies were conducted previous to the 1960's. Maps by Baranov and others (1967), Pratt and Walton (1974), Scholl and others (1974), and Schumacher (1976) improved coverage, but the Navarin basin area has received little detailed attention, and consequently inaccuracies abounded, especially northwest of Zhemchug Canyon. The present study improves coverage up to the U.S.-Russia Convention Line of 1867 and makes significant changes in the published bathymetry, especially in the Navarinsky Canyon area.

\section{DATA COLLECTION}

The data base for the map consists of over $23,000 \mathrm{kms}$ of $3.5 \mathrm{kHz}$ tracklines obtained on U.S. Geological Survey cruises from 1976 to 1982 (see inset tracklines map and table). Navigation was based on Loran $C$ updated with satellite fixes. On the continental shelf the trackline grid spacing averages about $30 \mathrm{~km}$. Digitized depths along each trackline were spaced $2 \mathrm{~km}$ apart on the continental shelf and rise and depths were spaced $0.2 \mathrm{~km}$ or less apart on the continental slope. We assumed a water velocity of 1500 meters/sec with no correction for tides, temperature, or salinity. Tides in the Bering Sea, although poorly understood, are generally less than a meter (Lisitsyn, 1969) and waves during the survey periods were negligible. The depth data and navigation data were computer merged, contoured by hand, and compared with a computer contoured map as a final check. Contour intervals range from $200 \mathrm{~m}$ for depths below $200 \mathrm{~m}$, to $25 \mathrm{~m}$ between 150 to $200 \mathrm{~m}$, to $10 \mathrm{~m}$ from 0 to $150 \mathrm{~m}$ water depths. Contours shallower than $100 \mathrm{~m}$ are taken from Pratt and Walton (1974) 
Table 1. Sources of bathymetric data

\begin{tabular}{lr} 
Cruise* & $\mathrm{km}$ of tr \\
\cline { 2 - 2 } $\mathrm{L}-5-76$ & 800 \\
$\mathrm{~S}-3-77$ & 700 \\
$\mathrm{~L}-5-77$ & 1,000 \\
$\mathrm{~L}-8-77$ & 2,300 \\
DC-4/5-80 & 6,800 \\
DC-2/3-81 & 10,100 \\
L- $10-82$ & 1,600
\end{tabular}

*Cruise identifier includes ship ( $L=S . P$. Lee, $S=S e a$ Sounder, DC=Discoverer), consecutive cruise number and year.

GEOLOGY

A tectonic model of the Bering shelf margin proposed by Scholl and others (1975) suggests that during the Mesozoic era the ocean plate boundary was a subduction zone of small convergence angle which ran along the present Bering shelf margin. As a result of subduction, fore-arc-eugeosynclinal rocks were uplifted and an inner magmatic arc formed (Marlow and others, 1976). Remnants of these fore-arc-magmatic-arc facies can be traced southeast from siberia through St. Matthew and St. Lawrence Islands, where they change trend to the northeast and extend into Alaska (Patton and others, 1976). Sometime in Cretaceous or earliest Tertiary time, the subduction zone either jumped or migrated to its present position at the Aleutian Trench (Scholl and others, 1975; Patton and others, 1976). With the cessation of subduction, both forearc and magmatic-arc rocks were uplifted and eroded. About the same time, the compressional deformation ceased and changed to extensional rifting (Marlow and others, 1976). Extension, erosion, and subsequent subsidence have continued during much of the Cenozoic, creating the Navarin basin, among others, and influencing much of the present bathymetry. Navarin basin contains as much as $12 \mathrm{~km}$ of fill in places beneath the continental shelf 
(Marlow and others, $1981 \mathrm{a}$ and $\mathrm{b}$ ). The sedimentary fill consists of semiconsolidated to unconsolidated, generally flat-lying, relatively undeformed, hemipelagic deposits of Cenozoic age (Scholl and others, 1968; Marlow and others, 1979; Karl and Carlson, 1982).

\section{GEOMORPHOLOGY}

The Navarin basin province is an area of great contrasts, including the very flat continental shelf with its subtle structures, to the steep continental slope with its spectacular precipices and large canyons, and the gentle continental rise crossed by turbidity current channels and buried deepsea fan channels. These morphologic features are influenced by, if not directly related to, the tectonic history of the region.

The continental shelf within the Navarin basin province is extremely flat and encompasses an area of $100,000 \mathrm{~km}^{2}$ between the $100 \mathrm{~m}$ and $150 \mathrm{~m}$ isobaths. The width of the shelf in the province varies from $100 \mathrm{~km}$ to $250 \mathrm{~km}$ and gradients range from $0.04^{\circ}$ to $0.01^{\circ}$. Compared to shepard's (1963) worldwide average shelf gradient of $0.12^{\circ}$, the Bering shelf appears to be one of the flattest in the world. The most prominent features are large canyons incised into the shelf and large submarine ridges oriented parallel to and located next to the shelf break. Two large submarine ridges, Navarin and Pribilof (Marlow and others, 1976), are each outlined by the $130 \mathrm{~m}$ isobath and are south of Pervenets and Zhemchug Canyons respectively. These ridges appear to be surface expressions of structural highs where acoustic basement rises to within less than one kilometer of the seafloor (Cooper and others, 1981). A few protrusions of probable acoustic basement crop out along these ridges, but are too small to show at this scale. Three such protruding knobs crop out on Navarin Ridge just north of Midale Canyon. Another knob, just south of Zhemchug Canyon, on Pribilof Ridge, rises to within 100 meters of the 
surface. The third and smallest ridge north of Pervenets Canyon, herein called Pervenets Ridge, is somewhat anomalous since shallow acoustic basement is not discernable on the seismic records.

The shelf break in Navarin basin province occurs between the 150-175 m isobaths. Around the canyons, the break varies somewhat; Navarinsky Canyon has no distinct shelf break, in Pervenets the break is very gentle, and in Zhemchug the break is very abrupt. In general, from northwest to southeast, the depth of the break decreases until at Zhemchug canyon the shelf break occurs at about $150 \mathrm{~m}$.

The continental slope, an area of $40,000 \mathrm{~km}^{2}$, begins at about the $150 \mathrm{~m}$ isobath and extends to the $2800 \mathrm{~m}$ isobath. The slope is dissected by five large submarine canyon systems which from north to south are Navarinsky, Pervenets, st. Matthew, Midale, and Zhemchug Canyons. It should be noted that all the above are large canyon systems, composed of numerous tributary canyons many of which are too small to resolve at our present grid spacing and map scale. The slope within the Navarin basin province has a length of $600 \mathrm{~km}$ and varies in width from $200 \mathrm{~km}$ near Navarinsky Canyon to $15 \mathrm{~km}$ near st. Matthew Canyon. The Navarin continental slope ranges in gradient from $3^{\circ}$ to $10^{\circ}$, compared to a world-wide average of $4.3^{\circ}$ (Shepard, 1963). Navarinsky Canyon has a width of $150 \mathrm{~km}$ at the shelf break, an axial length of $200 \mathrm{~km}$, and an approximate volume of $4900 \mathrm{~km}^{3}$. The Navarinsky system consists of two main branches, the western which is oriented roughly north-south and the eastern which trends northeast-southwest. Above the $400 \mathrm{~m}$ isobath, these branches form large, broad, gently sloping shelf valleys that 
have axial gradients of less than $0.2^{\circ}$. Between $400 \mathrm{~m}$ and $3600 \mathrm{~m}$, where these two branches merge into a single deep-sea fan channel, the gradients are about $1.2^{\circ}$. The gradient of the fan channel between 3200 and $3600 \mathrm{~m}$ is approximately $0.3^{\circ}$. Still, both of these gradients are gentle compared to the other Navarin margin canyons.

The next major canyon to the southeast, Pervenets, is incised

perpendicular to the slope and trends east to west. Pervenets Canyon has a width of $70 \mathrm{~km}$ at the shelf break, a downslope length of $120 \mathrm{~km}$, and a volume of $1200 \mathrm{~km}^{3}$; the major portion of this volume is above the $1000 \mathrm{~m}$ isobath. Above $1000 \mathrm{~m}$ the canyon bifurcates into two branches which can be traced to the $150 \mathrm{~m}$ isobath. Each of these main branches has an axial gradient of $0.4^{\circ}$. The larger northern branch located just south of Pervenets Ridge is well-defined, whereas the smaller southern branch of Pervenets Canyon is poorly developed and has little expression above 600 meters. Below 1000 meters the canyon system is less well-developed than any of the Navarin margin canyons. Between $1000 \mathrm{~m}$ and $3000 \mathrm{~m}$ the canyon thalweg attains a gradient of $3.8^{\circ}$.

The St. Matthew Canyon system, the smallest of the five canyons, contains some of the steepest relief in the Navarin basin area and is located south of the Navarin Ridge. St. Matthew Canyon consists of at least two main branches and several tributaries, the west branch with a gradient of $2.5^{\circ}$ being the longer and the east the shorter and steeper with a gradient of $5^{\circ}$ (Carlson and others, in press). The upper part of st. Matthew Canyon is parallel to Navarin Ridge and bounded to the southwest by the steep continental slope that 
reaches declivities of greater than $1^{\circ}$. Adjacent to St. Matthew Canyon is a large broad ridge about $30 \mathrm{~km}$ 1ong and $20 \mathrm{~km}$ wide in water depths between 400 $\mathrm{m}$ and $1000 \mathrm{~m}$. Another large linear ridge over $80 \mathrm{~km}$ long extends along the $177^{\circ} \mathrm{W}$ meridian and separates st. Matthew and Middle Canyons. Directly to the east of St. Matthew Canyon lies the Middle Canyon system which is very similar to the st. Matthew system, but twice as large (Carlson and others, in press). The east and west branches of Middle Canyon are roughly equal in size and each branch has two large and several smaller tributaries. The west branch is the steeper attaining a thalweg gradient of $4.1^{\circ}$ compared to a gradient of $3.2^{\circ}$ for the east branch. Neither the st. Matthew or Middle Canyon systems are incised into the shelf, perhaps due to the moderately well-consolidated nature of the sedimentary rocks and the apparent young age of both canyon systems. Zhemchug Canyon, located in the southeast corner of the Navarin Basin province, is perhaps the most spectacular of all the Navarin margin canyons. with a length of $160 \mathrm{~km}$ and $\mathrm{a}$ width of $40 \mathrm{~km}$, this canyon has a volume of over $6300 \mathrm{~km}^{3}$. The upper half of the Zhemchug Canyon system is incised deeply into the continental shelf between Navarin Ridge and Pribilof Ridge. The main thalweg of this giant canyon cuts deeply through the structural high formed at the shelf break by Pribilof Ridge and debouches onto the continental rise at a depth of about $2600 \mathrm{~m}$. The axial gradient of this canyon is about $2^{\circ}$ and the gradient of the fan channel is $1^{\circ}$. Numerous small tributaries run into the main canyon and numerous small slumps occur on its sides. A long ridge, total length of $130 \mathrm{~km}$ separates Zhemchug and Middle Canyons. This ridge has a maximum relief of about $1200 \mathrm{~m}(1800-3200 \mathrm{~m})$, and extends from the shelf edge across the slope and intersects the rise. 
The continental rise begins at the $2800 \mathrm{~m}$ isobath at the base of the slope and continues beyond the $3600 \mathrm{~m}$ isobath, the limit of our bathymetric data. The rise varies in width from $25 \mathrm{~km}$ to $100 \mathrm{~km}$ and gradient from $0.5^{\circ}$ to 1.8०. Many deep sea channels dissect the rise and all five of the previously mentioned canyon systems have well developed channels that extend across the continental rise. Cores taken in and near these channels contain sand lenses and graded sand beds suggesting turbidity current deposition (Carlson and others, 1981b). 
REFERENCES CITED

Baranov, A. N., and others, eds., 1967, The World Atlas: Chief Administration of Geodesy and Cartography, under the Council of Ministers of the U.S.S.R., 2nd ed., Moscow, 250 p. (English edition).

Carlson, P. R., Karl, H. A., Johnson, K. A., and Fischer, J. M., 1981b, Submarine canyons flanking Navarin Basin, Bering Sea, in U. S. Geological Survey in Alaska: Accomplishments during 1980: U. S. Geological Survey Circular 844, p. 139-141.

Carlson, P. R., Fischer, J. M., and Karl, H. A., in press, Two newly discovered submarine canyons on the Alaskan Continental Margin of the Bering Sea: U. S. Geological survey Open-File Report 82-

Cooper, A. K., Marlow, M. S., Parker, A. W., and Childs, J. R., 1981, Structure contour map on acoustic basement in the Bering Sea: U. S. Geological Survey Miscellaneous Field Studies Map MF-1165.

Karl, H. A. and Carlson, P. R., 1982, Location and description of sediment samples: Navarin Basin province, Bering Sea, 1980-81: U. S. Geological Survey Open-File Report $82-958,5$ p., 2 map sheets scale 1:1,000,000.

Lisitsyn, A. P., 1966, Recent sedimentation in the Bering Sea: Akad. Nauk SSR Inst. Okea1., Moskva, (Israel Program for Sci. Translations, 1969; U. S. Dept. of Commerce, Clearinghouse for Federal Sci. Tech. Info., Springfield, VA, 614 p.). 
Marlow, M. S., Scholl, D. W., Cooper, A. K., and Buffington, E. C., 1976, Structure and evolution of Bering Sea shelf south of St. Lawrence Island: American Association Petroleum Geologist Bull., v. 60, p. 161-183.

Marlow, M. S., Cooper, A. K., Scholl, D. W., Vallier, T. I., and McLean, H., 1979, Description of dredge samples from the Bering sea continental margin: U. S. Geological Survey Open-File Report 79-1139, 5 p.

Marlow, M. S., Carlson, P. R., Cooper, A. K., Kar1, H. A., McLean, H., McMullin, R., and Lynch, M. B., 1981a, Resource Report for proposed OCS sale number 83 Navarin Basin, Alaska: U. S. Geological Survey Open-File Report 81-152, $82 \mathrm{p}$.

Marlow, M. S., Cooper, A. K., Parker, A. W., and Childs, J. R., 1981b, Isopach map of strata above acoustic basement in the Bering sea: U. S. Geological Survey Miscellaneous Field Studies Map MF-1164.

Patton, W. W., Lanphere, M. A., Miller, T. P., and Scott, R. A., 1976, Age and tectonic significance of volcanic rocks on St. Matthew Island, Bering Sea, Alaska: U. S. Geological Survey, Journal of Research, v. 4, p. 6773.

Pratt, R., and Walton, F., 1974, Bathymetric Map of the Bering Shelf: Geological Society of America, Inc., Boulder, Colo.

Shepard, F. P., 1963, Submarine geology, 2nd ed.: Harper and Row, New York, 557 p. 
Scholl, D. W., Buffington, E. C. and Hopkins, D. M., 1968, Geologic history of the continental margin of North America in the Bering Sea: Marine Geology, v. 6, p. 297-330 .

Scho11, D. W., Alpha, T. R., Marlow, M. S., and Buffington, E. C., 1974, Base map of the Aleutian-Bering Sea region: U. S. Geological Survey Miscellaneous Investigation Series Map I-879, scale 1:2,500,000 .

Scholl, D. W., Buffington, E. C., and Marlow, M. S., 1975, Plate tectonics and the structural evolution of the Aleutian Bering sea region, in Forbes, R. B., ed., Contributions to the geology of the Bering sea Basin and adjacent regions: Geological Society of America Special Paper 151, p. 1-32.

Schumacher, G. M., 1976, Bathymetric map of the Aleutian Trench and Bering Sea: U. S. Geological Survey Open-File Map 76-821, scale 1:2,500,000. 